\title{
AN INTRODUCTION AND BACKGROUND TO THE BAITFISH RESEARCH PROJECT IN EASTERN INDONESIA
}

\author{
S.J.M. Blaber ${ }^{*}$
}

Pole-and-line fishing for tuna is a multi-million dollar industry in eastern Indonesia that employs many people, supports several canneries and generates export income. In contrast to the more industrial tuna fisheries in the Pacific it comprises many thousands of small artisanal wooden vessels and separate baitfish catching vessels. Its development is presently constrained by a shortage of baitfish, the important species of which are also utilised as human food in this region. There has been a lack of data on the exploitation and stocks of the baitfish used by the fishery in Indonesia.

In order to help answer some of these questions a collaborative research project between CSIRO (Australia) and the Research Institute for Marine Fisheries (RIMF) (Indonesia) on tuna baitfish in eastern Indonesia began in July 1995 and ran until 1999. This project resulted from approaches by the Indonesian government to CSIRO and formal requests for funding to the Australian Centre for International Agricultural Research (ACIAR).

A feasibility study was completed in May 1994 and identified the most pressing problems that could be tackled by an ACIAR/CSIRO project. Also at the instigation of ACIAR, those technical baitfish handling aspects of the problem that could not be tackled by an ACIAR project were taken up by the Western Pacific Fisheries Consultative Committee (WPFCC) who undertook a field survey of tuna baitfish capture and handling techniques in eastern Indonesia in September 1993 (Itano, 1993) funded through Canadian aid. Their report (Itano, 1993) includes comprehensive data on fishing vessels, fleet sizes, baitfishing techniques, baitfish catch species composition and problems associated with baitfish supply. It also makes recommendations for improving the efficiency of the industry.

The ACIAR/CSIRO feasibility study showed that the important biological problems were in relation to data analysis, stock assessment and overall management. Hence the collaborative
CSIRO/RIMF project aimed to analyse all existing baitfish catch records, to provide stock assessment and biological data, to train Indonesian fishery scientists, and to develop appropriate manage ment plans for the sustainable use of baitfish.

The Indonesian State Fisheries Enterprises had a major role in the project and were involved in the research and will utilise the results. The main beneficiaries of the project are the many thousands of artisanal tuna fishermen and similar numbers of coastal people involved in catching baitfish, as well as the fishing companies, both state and private, which buy most of the tuna caught by the artisanal fishermen. The research was able to capitalise on the experience and expertise gained during previous successful ACIAR funded CSIRO studies of tuna baitfish in the $\mathrm{Pa}$ cific and Indian Oceans. This research led by CSIRO began in 1986 in the Solomon Islands and the Maldives, and the results from the project were reported at an international baitfish conference in Honiara in December 1989 (Blaber \& Copland, 1990). The outcomes engendered much interest throughout the South Pacific, and led to a second phase of the project incorporating Kiribati and Fiji from 1990 to 1993 . An extensive series of scientific papers and fisheries articles resulted from the baitfish projects and a complete bibliography is included in this introduction. Most of the important biological and ecological questions about baitfish had been answered during the course of the research, and hence the work in Indonesia that began in 1995 could be tightly focused on issues particular to, and critical to the fishery in eastern Indonesia - namely, analysis of existing catch data, ways of assessing stocks, and management options.

Prior to the collaborative project the Indonesian Research Institute for Marine Fisheries in Indonesia had already undertaken considerable research into various aspects of baitfishing, much of which was relevant to, and provided vital background for the project. It included:

"' CSIRO Marine Research. Cleveland, Queensland 4163, Australia 
- Studies of live-bait fishing techniques in Maluku (Gafa \& Subani, 1987, 1991).

- Analyses of the species composition of baitfishes caught in Ambon (Andamari et al., 1987)

- Detailed surveys of catch levels and seasonal bait availability (Rumarupute et al., 1987; Gafa \& Subani, 1991; Wahyuono \& Rusmadji, 1987).

- Detailed biological studies of Encrasicholina devisi and $E$. heterolobus in the Ambon region (Banjar \& Talaohu, 1987; Banjar \& Andamari. 1990).

- Studies of Sardinella fimbriata in Maluku (Hurasan et al., 1990).

- Dr. Sumadhiharga of LIPI and Pattimurra University at Ambon had also carried out biological research into Stolephorus species in Ambon Bay and expertise exists in these institutions although much of the work still remains unpublished.

This special issue of the Indonesian Fisheries Research Journal contains the papers resulting from the collaborative (SIRO/RIMF project and the baitfish workshop held in Manado, North Sulawesi in July 1998.

Papers in this volume start with a description of the background to, and progress in resourcebased fisheries management in eastern Indonesia (Soepanto). This is followed by an overview of the tuna pole-and-line and fishery and the associated baitfishery (Naamin \& Gafa). Next there is a paper by Rawlinson et al. describing in detail the catch statistics and history of the tuna baitfishery. Three papers by Andamari et al. examine the reproductive biology and gonad maturity of anchovies, and the stageing and natural mortality of anchovy eggs - all essential inputs to the daily egg production method of estimating the biomass needed for stock assessments described in the final paper by Milton et al.

The results can be used now, and in the future, by the Central, Provincial and Regency government agencies responsible for the wise management of fisheries resources in eastern Indonesia - a task that is vital to the wellbeing of the fishing companies, fishers and coastal peoples of the region.

\section{Acknowledgments}

The involvement of (SIRO) with baitfish research owes much to the foresight of John Copland (ACIAR) who instigated the first project and to
Barney Smith (ACIAR) who continued this support for subsequent projects. A large number of scientists and fishermen have contributed to the success of the baitfish research projects funded by ACIAR. Most recently, in Indonesia the support of Dr Fuad Cholik, Director of CRIFI and his successor, Dr. M. Fatuchri Sukadi is particularly acknowledged, as is the great assistance of the ACIAR Indonesia Country Manager, Ronald Rakiman. We are also grateful to Dr Tony Lewis (South Pacific Commission) and Professor Ian Pot. ter (Murdoch University) for scientific advice and support throughout the baitfish projects. The publication of this volume was made possible by funding from ACIAR (9424).

\section{REFERENCES}

Andamari R., Hasan, N. and Zubaidi, T. 1987. Composition of bait-fishes caught by "Bagan" in Baguala Bay, Ambon Island. J. Penelitian Perikanan Laut 43: $51-58$.

Banjar, H. and Talaohu, S.H. 1987. A study on Stolephorus heterolobus and its relation to bait fisheries in Tulehu Bay (Central Moluccas). J. Penelitian Perikanan Laut 44: 25-30.

Banjar, H. and Andamari, R. 1990. Sex ratio, gonad maturity and fecundity of anchovies Stolephorus devisi in Saparua. J. Penelitian Perikanan Laut 55: 1.7.

Blaber, S.J.M. and Copland, J.W. (eds.). 1990. Tuna Baitfish in the Indo-Pacific. ACIAR Proceedings 30: $211 \mathrm{pp}$.

Gafa, B. and Subani, W. 1987. Study on live bait fishing for the small-scale fisheries development in Halmahera and Morotai. J. Penelitian Perikanan Laut 42: 97-105.

Gafa, B. and Subani, W. 1991. Fishing gear, fishing season, fishing areas, exploitation level and development of livebait in Maluku waters. J. Penelitian Perikanan Laut 61: 33-50.

Hurasan, M.S., Bandjar, H. and Syam, A.R. 1990. Analysis on biological aspects of Sardinella fimbriata in Paperu, Saparua Bay. J. Penelitian Perikanan Laut 55: 29-39.

Itano, D.G. 1993. The development of the Indonesian pole-and-line fishery in relation to the efficient utilisation of live baitfish resources. Phase 1: Field survey of tuna baitfish capture and handling techniques in eastern Indonesia. Unpublished Report WPFCC Consultative Committee, Manila, Philippines.

Rumahrupute, B., Syukur, M. and Letelay, J. 1987. Survey on fish bait in Central Maluku. J. Penelitian Perikanan Laut 43: 75-80.

Wahyuono, H. and Rusmadji. 1987. Lift net fishery in Jepara waters. J. Penelitian Perikanan Laut 43: 81 . 88 


\section{BIBLIOGRAPHY OF BAITFISH PUBLICA- TIONS FROM CSIRO/ACIAR BAITFISH PROJECTS (1986-1998)}

\section{Scientific Journals and Books}

Blaber, S.J.M. 1994. Fisheries in the South Pacific. In Moritz, C., Kikkawa, J. and Doley, D. (eds.). Con. servation Biology in Australia and Ocrania. Sydney. Surrey Beatty. p 197-208.

Blaber. S.J.M. and Copland, J. (eds.). 1990. Tuna Baitfish in the Indo-Pacific Region. ACIAR Proceedings 30: $211 \mathrm{pp}$

Blaber. S.J.M. and Milton. D.A. 1990. Species composition. community structure and zoogeography of fishes of mangroves in the Solomon Islands. Ma. rine Biology 105: 259-268.

Blaber, S.J.M., Milton, D.A., Rawlinson, N.J.F., Tiroba, G. and Nichols, P.V. 1990. Reef fish and fisheries in Solomon Islands and Maldives and their interactions with tuna baitfisheries. ACIAR Proceedings 30: $159-168$

Blaber, S.J.M., Milton, D.A. and Rawlinson, N.J.F. 1991. A checklist of fishes recorded by the Baitfish Research Project in Solomon Islands from 1986 to 1990. CSIRO Mar. Lab. Rep. Ser. 212: 1-24.

Blaber, S.J.M., Milton, D.A., Rawlinson, N.J.F., Tiroba, G. and Nichols, P. 1989. Diets of lagoon fishes of the Solomon Islands: Predators of tuna baitfish and trophic effects of baitfishing on the subsistence reef fishery. Fish. Res. 8: 263-286.

Blaber, S.J.M., Milton, D.A., Rawlinson, N.J.F. and Sesewa. A. 1994. Predators of tuna baitfish and the effects of baitfishing on the subsistence reef fisheries of Fiji. ACIAR Proceedings 52: 51-61.

Blaber, S.J.M., Milton, D.A., Rawlinson, N.J.F. and Sesewa, A. 1994. A checklist of fishes recorded by the Baitfish Research Project in Fiji from 1991 to 1993. ACIAR Proceedings 52: 102-112.

Leqata, J.L.. Rawlinson, N.J.F., Nichols, P.V. and Tiroba, G. 1990. Subsistence fishing in Solomon Islands and the possible conflict with commercial baitfishing. ACIAR Proceedings 30: 169-178.

Maniku, H.. Anderson, R.C. and Hafiz, A. 1990. Tuna baitfishing in Maldives. ACIAR Procepdings 30: 22 29 .

Milton, D.A. and Blaber, S.J.M. 1991. Maturation, spawning seasonality and proximal spawning stimuli of six species of tuna baitfish in Solomon Islands. Fish. Bull. U.S. 89: 221-237.

Milton, D.A., Blaber, S.J.M. and Rawlinson, N.J.F. 1990. Diet and prey selection of six species of tuna baitfish in three coral reef lagoons in the Solomon Islands. J. Fish Biol. 37: 205-224.

Milton, D.A., Blaber. S.J.M. and Rawlinson, N.J.F. 1991. Age and growth of tuna baitfish (Genus Spratelloides) in the tropical Indo-Pacific. J. Fish Biol. 39: 849-866.
Milton. D.A.. Blaber, S.J.M., Tiroba, G., Leqata, J.L., Rawlinson, N.J.F. and Hafiz, A. 1990. Reproductive biology of Spratelloides delicatulus, $S$. gracilis and Stol'phorus heterolobus from Solomon Islands and Maldives. ACIAR Proceedings 30: 89-99.

Milton. D.A., Blaber, S.J.M., Rawlinson. N.J.F., Hafiz, A. and Tiroba. G. 1990. Age and growth of major baitfish species in Solomon Islands and Maldives. ACIAR Procepedings 30: 135-141.

Milton. D.A.. Blaber, S.J.M. and Rawlinson, N.J.F. 1994. Reproductive biology and egg production of three species of clupeid from Kiribati, tropical central Pacific. Fish. Bull. U.S. 92: 102-121

Milton, D.A., Blaber, S.J.M. and Rawlinson, N.J.F. 1993. Age and growth of three tropical clupeids from Kiribati, central south Pacific. J. Fish Biol. 43: 89. 108.

Milton, D.A., Blaber, S.J.M. and Rawlinson, N.J.F. 1994. Diet, prey selection and their energetic rela. tionships with reproduction in the tropical herring, Herklotsich thys quadrimaculatus, in Kiribati, central Pacific. Mar. Ecol. Prog. Ser. 103: 239.250.

Milton, D.A. and Blaber, S.J.M. 1994. Aspects of growth and reproduction relevant to managing baitfish stocks in Fiji. ACIAR Proceedings 52: 79-91.

Milton, D.A., Rawlinson, N.J.F. and Sesewa, A. 1994. Species composition and community structure of tuna baitfish populations in Fiji. ACIAR Proceedings 52: $92-101$.

Milton, D.A., Blaber, S.J.M. and Rawlinson, N.J.F. 1995. Fecundity and egg production of four species of short-lived clupeoids from Solomon Islands, tropical South Pacific. ICES J. Mar. Sci. 52: 111-125

Nichols, P.V. and Rawlinson, N.J.F. 1990. Development of the pole-and-line fishery in Solomon Islands with reference to the baitfishery and its management. ACIAR Proceedings 30: 30-44.

Rawlinson, N.J.F. 1990. Catch composition of the tuna baitfishery of Solomon Islands and possible impact on non-target species. ACIAR Proceedings 30: 190 210 .

Rawlinson, N.J.F. and Nichols, P.V. 1990. Analysis of catch and effort data for the Solomon Islands baitfishery. ACIAR Proceedings 30: 179-189.

Rawlinson, N.J.F., Milton, D.A. and Blaber, S.J.M. 1992. Tuna Baitfish and the Pole-and-Line Industry in Kiribati. ACIAR Tech. Rep. 24: 1-90.

Rawlinson, N.J.F., Sesewa, A. and Milton, D.A. 1994. A survey of fishing activity by coastal villages in Fiji and the possible conflict with tuna baitfishing ACIAR Proceedings 52; 62-69.

Rawlinson, N.J.F. and Sesewa, A. 1994. Potential sites for baitfishing in Fiji. ACIAR Proceedings 52:70-78.

Rawlinson, N.J.F. and Sharma, S.P. 1994. Analysis of historical baitfish catch-and-effort in Fiji and an assessment of the current status of the stocks. ACIAR Proreedings 52: 26-48. 
Rawlinson, N.J.F. 1994. A review of previous baitfish studies and reports in Fiji. ACIAR Procepedings 52: 8-25.

Sharma, S.P. 1994. Fiji baitfishery status report. ACIAR Proceedings 52: 3-5.

Sharma, S.P. 1994. Customary fishing rights in Fiji and their effects on compensation payments for com. mercial baitfishing activities in Fiji. ACIAR Pro. ceedings 52: 49-50.

Tiroba, G., Rawlinson, N.J.F., Nichols, P.V. and Leqata. J.L. 1990. Length-frequency analysis of the major baitfish species in Solomon Islands. ACIAR Proreed ings 30: 114-134.

Tiroba, G. 1994. The current status of commercial baitfishing in Solomon Islands. ACIAR Proceedings 52: $113 \cdot 116$.

Wise. B. and Potter, I.C. 1994. Length-frequency data for tuna baitfish (Encrasicholina heterolobus and Spratelloides delicatulus) and the cardinal fish (Apogon rueppellii): Guidelines for employing computer packages to use length-frequency data to analyse age composition and growth of fish populations. ACIAR Proceedings 52: 117-130.

\section{Fishery Reports}

Anderson, R.C. and Hafiz, A. 1988. The Maldivian livebait fishery. Third Expert Consultation on the Stock Assessment of Tunas in the Indian Ocean. Mauritius 22-27 June, 1988. Marine Research Section, Maldives.

Beckman, R. 1991. Fishing in paradise. Ecos 70: 3435 .

Blaber, S.J.M. 1988. Tuna Baitfish Research Project. Rasain Newsletter, Maldives 1: 6-7.

Blaber, S.J.M. 1989. Tuna Baitfish Research Project a progress report. Rasain Newsletter, Maldives 2: 19-21.

Fearn, M.J. 1991. An Evaluation of the Imparts of Research on Baitfish for the Tuna Fisheries of Selected Developing Countries. M.Ec. dissertation, Faculty of Economic Studies, University of New England. ACIAR Econ. Ass. Ser.

Nichols, P.V. 1988. A Report on A Collaborative Research Programme into Baitfish Populations in Solomon Islands, With Some Preliminary Findings. Workshop on Pacific Inshore Fishery Resources, Noumea, New Caledonia, 14-25 March, 1988. South Pacific Commission Information Paper No. 8.

Rawlinson, N.J.F. 1989. Population dynamics of the commercially important baitfish species Stolephorus heterolobus in Solomon Islands. Fishbyte 7(1): 12 . 17.

Rawlinson, N.J.F. 1989. Fishing competitions as a means of data collection. Fishbyte $7(2): 22$.
Rawlinson. N.J.F. 1990. Report from Trip With FV Nei Kaneati, 27 June - 1 July 1990. Report to Te Mautari Ltd., Tarawa. Kiribati. 5 pp.

Rawlinson. N.J.F. 1990. Report on Trials to Introduce the Use of Generator Boats in Order to Increase nightly Baitfish Catches by Te Mautari Ltd. poleand-line Fishing Vessels in Kiribati. Report to Te Mautari Ltd., Tarawa, Kiribati. 6 pp.

Rawlinson, N.J.F. 1990. Observations Made during Trip Onboard the South Pacific Commission's Tagging Vessel "Te Tautai" with Special Reference to Their Implications for Pole-and-line Fishing Vessels in Kiribati. Report to Te Mautari Ltd., Tarawa, Kiribati.

Rawlinson, N.J.F. 1990. Baitfish Research Project-trip to Butaritari 2 December 12 December 1990. Report to Fisheries Division, Tarawa, Kiribati. 8 pp.

Rawlinson, N.J.F. 1990. Baitfish Research Project - trip to Butaritari 6 January - 18 January 1991. Report to Fisheries Division, Tarawa, Kiribati. 8 pp.

Rawlinson, N.J.F. 1991. Tarawa Lagoon Fishing Competition. Report to Fisheries Division, Tarawa, Kiribati. 6 pp.

Rawlinson, N.J.F. 1991. Royalty Payments as Compensation for the Capture of Baitfish in Fiji Based on the Methods used in Solomon Islands. Report to Fisheries Division, Fiji.

Rawlinson, N.J.F. 1992. Explanatory notes for a Database Containing a Compilation of All Existing Baitfish Catch and Effort Data for the Republic of Kiribati. Report to Fisheries Division, Tarawa, Kiribati.

Rawlinson, N.J.F. 1992. List of Species and Catches of Non-baitfish Made During the ACIAR/CSIRO Baitfish Research Project in the Republic of Kiribati. Report to Fisheries Division, Tarawa, Kiribati.

Rawlinson, N.J.F. 1992. Bycatch from Cast Net Operations during Sampling for the ACIAR/CSIRO Baitfish Research Project in the Republic of Kiribati. Report to Fisheries Division, Tarawa, Kiribati.

Rawlinson, N.J.F. 1992. Baitfish Project Survey to Southern Yasawa Islands and the Mamanuca Islands, 21/1/92 - 17/2/92. Report to Fisheries Division, Fiji.

Rawlinson, N.J.F. 1992. Baitfish. A guide for Fisheries Officers and Extension Officers. Report to Fisheries Division, Fiji.

Rawlinson, N.J.F. 1993. Subsistence Fisheries Questionnaire Survey of Viti Levu - Field Manual. Report to Fisheries Division, Fiji.

Tiroba, G. 1990. A Preliminary Account of the Population Dynamics of Stolephorus devisi (Engraulidae) at Munda baitground, Solomon Islands. Fishbyte 8: 26-27. 